\title{
Intention to Quit and the Demand Control Model: A Case of Malaysian Multimedia Super Corridor Status Companies
}

\author{
Shahrul Nizam bin Salahudina \\ Abdullah Osman ${ }^{b}$ \\ Muhammad Safizal Abdullahc \\ Afdzal Aizat Ramlia \\ Siti Noreen Annuar Lima \\ aCollege of Business, University Tenaga Nasional, 26700 Muadzam Shah, Pahang; bKulliyah Muamalat, Insaniah University \\ College, 09300 Kuala Ketil, Kedah; ' SChool of Business Innovation \&Technopreneurship, Universiti Malaysia Perlis \\ 01000 Kangar, Perlis, Malaysia
}

Doi:10.5901/mjss.2016.v7n2p217

\begin{abstract}
In the fast paced global economy where trades are being conducted everywhere and at any time, the focus of organizations has shifted from the traditional view of producing what they think are needed by the market to a new paradigm whereby they are now to produce products or services that the markets desire literally. One requirement of surviving in such challenging business environment is to be able to retain performing employees whereby employee loyalty has been a thing of the past. This study will look into three critical factors that are often associated with unwelcome behaviors in the organizations such as low motivation, low organizational commitment, less satisfaction which in turn will lead to lower productivity, creativity and innovations and may result in employees quitting. The main objectives of this particular study are to explore the degree of intention to quit, examine relationships between job demands; job control; social support with turnover intention; also to examine the ability of the demand control variables (Karasek, 1979) in explaining turnover intention among IT executives. The sector which is being investigated is the small and medium companies which operate in the IT related businesses particularly Small and Medium companies in Malaysia. Results showed that only job demand and job control have significant associations with turnover intention and subsequently the demand control model is unable to explain the variances in turnover intention
\end{abstract}

Keywords: Turnover, Demand Control, IT, MSC

\section{Small \& Medium Enterprises (SMEs) in Malaysia}

SMEs in Malaysia are being represented by 645,136 establishments and counted for $97.3 \%$ of total businesses operating in the country (DOS, 2011) of which approximately $90 \%$ establishments are in the services sector, $6 \%$ manufacturing, $3 \%$ are constructions associated while the rest are agriculture (1\%) and quarrying (0.01\%). The growth of SMEs in Malaysia has seen an increase of almost $3 \%$ from $29.4 \%$ (DOS, 2005) to 32.5\% (DOS, 2011) and for within certain period between 2006 and 2011, the registered growth of the SMEs increased more than the national economic growth, whereby in the year 2011, the growth registered by SMEs was 6.8\% compared to Malaysia's economic growth of 5.1\% (DOS, 2011). These numbers represent the importance and significant contributions of SMEs in the Malaysian economy.

SMEs in Malaysia are categorized as such based particularly on 2 criteria which are, the total count of employees an organization has or the annual sales turnover recorded by the organization. However, the numbers to meet the requirement of the council varies due to different sectors which the organization operates in. A SME in the services sector must not employ exceeding more than 50 full time employees at one time, also with sales turnover of not more than RM 5 million and since IT related businesses in Malaysia are mainly dealing with services, this study will adopt these two as its base requirements as well. As such, only IT related SMEs which fulfills the base requirements were included in this study. The fundamental judgment in choosing this specific sector is that the nation's aspirations of becoming a developed country lies significantly in the ability of this sector to drive the economy from its current standings to an economy that is based on the principles of creativity and innovations. 


\subsection{Labor Turnover in Malaysian SMEs}

Nowadays, top executives recognizes the importance of labor turnover; especially those related to talent leaving their organizations.. Turnover has many consequences; as such Siong et al (2006) mentioned that organizations will incur costs of training, and loss of productivity to name few. That's why many organizational psychologists have proposed many antecedents to labor turnover and many scholarly researches have been done in the context of understanding turnover among members of organizations and much of it were empirical in nature and have addressed the various determinants of turnover (Sager \& Griffeth, 1998).

In Malaysia, among others, labor turnover in SMEs was mentioned as one of the problem that are faced by small and medium firms both domestically as well as globally (Nasurdin et al. 2004, 2005; Pattie, 2006; Ross, 1996; Shain, 1999). Recent findings by Michael Page International (2012) survey that concluded that $83 \%$ of the respondent of the study in Malaysia are very likely or likely to quit their present jobs. This is very much significant empirically especially when the figure for employment in this sector as of 2011 is 3,669,229 (DOS, 2012), therefore a rough figure of between 700,000 and 750,000 employees will decide to quit their jobs annually and $90 \%$ of these turnovers happened in the services sector. This number is too large to be ignored.

\subsection{Work-Related Contributing Factors for Labor Turnover}

Employment plays a crucial role in the lives of many individuals. Ever increasing challenges in the workplace as the result of the global marketplace and stiff competition among organizations in line with the battle for the dominancy in market or even survival, has put much pressure on workers (Hoel et al., 2000). In turn, workers will display or behave accordingly to these challenges whilst prolonged unchecked pressures will result in workers displaying sets of negative behaviors and eventually affect the organizations' performance (Chen et al., 2011). Henceforth, workers will start to think whether the job fits them and ultimately if no further interventions, workers develop the intention to quit.

Throughout time and scholarly based articles, many have concluded that there are too many reasons why employees choose to leave their organizations or having the intent to do so. Factors such as high job demand, social support, physical environment of workplace, physical exertion, and job dissatisfaction (Karasek, 1979; Schnall \& Landbergis, 1994; Kristensen, 1995, 1996; Graham, 1999; Aizzat et al, 2003; Pattie, 2006) were empirically proven to affect the ability of SMEs to retain their capable employees will in turn affect firm's performance(Batra \& Tan, 2003).

\subsection{Turnover}

Turnover is defined as the degree of individual movement across the membership boundary of an organization (Price, 1997). Meanwhile, the bureau of Labor statistics (1966) used the word of turnover to describe both organizational turnover accessions and separations. Similarly, Jaros (1997) defined turnover intention as employees' tendency to stop being a member of the current organization. Furthermore, turnover also can be referred to individuals that voluntarily quit and/or resigned (Price, 1997), and the focuses of researches are more on members leaving rather than entering the organization (Price, 2000). Also, further explanation and understanding of this subject is important to organization due to the fact that turnover adversely affect organizational effectiveness (Hom \& Griffeth, 1995). Furthermore, Price (2000) mentioned that turnover has wide negative impact to man power planning in the organizations. This in turn will further disintegrate the organization ability to recruit good personnel and in the long run if turnover phenomenon is left alone without appropriate study, it will ultimately effect the organization to function accordingly (Price, 2000).

\subsection{Turnover: The Intent Factor}

Intentions to quit have been generally accepted as important antecedents to turnover and that intention to quit is represented by an attitudinal orientation or a cognitive manifestation of the behavioral decision to quit (Elangovan, 2001). Additionally, Firth et al. (2003) stated that intention to quit is the primary indicator of the actual turnover behavior. As suggested by Udo, Guimaraes and Igbaria (1997), many empirical research models of turnover of employees suggested that actual behavior are always the results of behavioral intentions. Furthermore, these statements are supported by the findings of Steele and Ovalie (1984) who suggested a strong relationship between intent to leave \& the actual turnover. In addition, Alexander et al. (1998) also reported quitting intention is best taken as the antecedent of the real turnover behavior and similarly, Ajzen and Fishbein (1980) agreed that the many instant causes of actual turnover are the intentions themselves. Moreover, according to Jaros et al. (1993), turnover intention is the direct forerunner of turnover 
conduct and echoes a mixture of withdrawal behaviors. Therefore it is acceptable to measure actual turnover by determining the level of intent to leave reported by employees themselves (Igbaria \& Greenhaus, 1992).

\section{The Demand Control Model}

Karasek (1979) introduced the job strain model by which many of the research on stress were based on (Jonge et al., 2000). Moreover, the model has been used over and across cultures and countries (Tsutsumi et al, 2002; Bosma et al, 1998; Malinauskiene et al, 2004) hence suggest its reliability, compatibility and functionality. This model incorporated the interaction between psychosocial demands and decision latitude. The three variables that were incorporated in this model are Job Demand, Social Support and Job Control. Most of the literature available associated with the demand-control model associated the ability of these three variables to explain stress in the workplace. The results of these prior studies showed that these three are able to significantly explain stress or job strains (Karasek \& Theorell, 1990; Jonge, Janssen \& Van Breukelen, 1996; Demerouti et al., 2001; Houkes et al., 2001; Aurbech et al., 2003; Johnson, 1986; Wallgren \& Hanse 2007). Nonetheless, there are available literatures that exposed the ability of the said variables for explaining turnover intention (Borda \& Norman, 1997; Rahim, 1997; Price \& Mueller, 1986; Kim et al., 1996; Gaertner, 2000; Van Dyne et al., 2004; Viator, 2001; Allen, 2001). However, most of the literature did not directly test those three variables against turnover intent and had used other factors such as job satisfaction, well-being, stress, organizational commitment and even job dissatisfaction for explaining turnover. Hence a lack of evidences linking directly the variables and turnover intent, reiterates the need to investigate this matter closely.

\section{Research Framework}

This study intends to examine the ability of the demand-control variables in explaining intention to quit among workforces of the Malaysian SMEs. Based on literature examinations, a research framework was developed based on the lack of evidences of previous literature in examining the direct effect of the demand-control model on turnover intention as per figure 1.

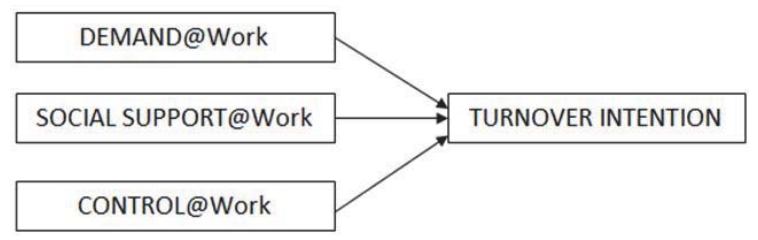

Figure 1: The Demand-Control Model of Turnover Intention

Based on the framework in figure 1, the study is proposing these set of hypotheses:

$\mathrm{H}_{1}$ : The levels of Intention to quit among respondents are high

$\mathrm{H}_{2}$ : Relationship between Demand@Work and Turnover Intention exist

$\mathrm{H}_{3}$ : Relationship between Social Support@Work and Turnover Intention exist

$\mathrm{H}_{4}$ : Relationship between Control@Work and Turnover Intention exist.

$\mathrm{H}_{5}$ : Demand Control variables significantly affect Turnover Intention

\section{Methodology}

The study had used the simple random sampling method to select the IT executives that were included in the data collection phase. The population was identified using one master list available from SMIDEC (Small and Medium Corporation of Malaysia) through their website www.smidec.com.my. The total small and medium establishments in Malaysia within the ICT sector is 708 and many are concentrated in four areas namely, Selangor (266), Kuala Lumpur (163), Pulau Pinang (71) and Johor (41), whereas the remaining 167 companies are scattered elsewhere. Since there is no list available for the total number of IT executives working in this sector, the study had chosen to take the total number of establishments as its population list. The companies were then selected randomly and questionnaires were administered to one IT executives from each of the companies. Based on the total number of establishments (708), the 
total number of sample was determined at 248 (Krejcie \& Morgan, 1970). Table of random numbers was then employed to select the 248 companies to be included in the study.

\section{Questionnaire Development}

Although the study had stated that the demand control model was used, the observed variables were developed anew but systematically enhanced based on the original demand-control model. This means that the study has developed its own set of items to represent the latent variables of the demand control model. The base of the model was left intact with three latent variables, only renamed; Demand at work, Social Support and Job Control.

Items are design in such a way that it limits the scope of the measurements to just work-related questions. This is important due to the fact that individuals tend to mix up work and other things in their lives and it is the intent of this study to limit the perceptions of the subjects involved only to their work. Some items from the original demand control model were dropped while some new items were inserted and some are rephrased. The final version of the items included in the questionnaire was vetted through by IT Executives from IBM Malaysia and they agree that the items were reflective of their work. Additionally, one pilot study was conducted in order to test the ability of the new items in explaining the measurement constructs of the demand control model $(\mathrm{N}=30)$. This is to make sure that the items used are valid and measure the intended latent variables. The first variable that was included in this study is named Work Related Demand and is being observed through two observed variables which are physical and mental demand at work. Physical Demand and Mental Demand are both represented through 4 items; whereby the items are directed towards assessing the executives' physical and mental demands at work. The second variable in the demand control model is named Social Support and this construct measurement is being represented by 5 items which intend to assess the IT Executives social support at work. The third variable is Job Control and is being represented by 8 items which assessed the executives' empowerment and skills discretions.

\section{Factor Analysis}

Factor analysis was done separately for each of the variables. This is done to measure the unidimensionality, validity and reliability requirements.

Work Related Demand (Physical Demand)

Table 1: Total Variance Explained \& Eigenvalue of Physical Demand

\begin{tabular}{|c|c|c|c|c|c|c|}
\hline \multirow{2}{*}{ Component } & \multicolumn{5}{|c|}{ Initial Eigenvalues } & \multicolumn{3}{|c|}{ Extraction Sums of Squared Loadings } \\
\cline { 2 - 7 } & Total & \% of Variance & Cumulative \% & Total & $\%$ of Variance & Cumulative \% \\
\hline 1 & 2.667 & 66.686 & 66.686 & 2.667 & 66.686 & 66.686 \\
2 & .620 & 15.511 & 82.197 & & & \\
3 & .496 & 12.400 & 94.597 & & & \\
4 & .216 & 5.403 & 100.000 & & & \\
\hline
\end{tabular}

According to table 1 , one factor was extracted with eigenvalue exceeds 1 whilst the total variance explained stood at $67 \%$. This factor is named physical demand which measures physical demands of the IT executives at work.

Work-Related Demand (Mental Demand)

Table 2: Total Variance Explained \& Eigenvalue of Mental Demand

Variance Explained

\begin{tabular}{|c|c|c|c|c|c|c|}
\hline \multirow{2}{*}{ Component Initial Eigenvalues } & \multicolumn{3}{c|}{ Extraction Sums of Squared Loadings } \\
\cline { 2 - 7 } & Total & \% of Variance & Cumulative \% & Total & \% of Variance & Cumulative \% \\
\hline 1 & 2.529 & 63.231 & 63.231 & 2.529 & 63.231 & 63.231 \\
2 & .762 & 19.052 & 82.283 & & & \\
3 & .438 & 10.943 & 93.226 & & & \\
4 & .271 & 6.774 & 100.000 & & & \\
\hline
\end{tabular}


In table 2 we can see that 1 factor has emerged from the analysis with the eigenvalue of more than 1 with the total variance explained of $64 \%$. This factor is named mental demand and it measures the mental aspect of demands placed on the IT Executives.

\section{Social Support}

Table 3: Total Variance Explained \& Eigenvalue of Social Support

\section{Variance Explained}

\begin{tabular}{|c|c|c|c|c|c|c|}
\hline \multirow{2}{*}{ Component } & \multicolumn{4}{|c|}{ Initial Eigenvalues } & \multicolumn{3}{c|}{ Extraction Sums of Squared Loadings } \\
\cline { 2 - 7 } & Total & \% of Variance & Cumulative \% & Total & \% of Variance & Cumulative \% \\
\hline 1 & 3.181 & 63.624 & 63.624 & 3.181 & 63.624 & 63.624 \\
2 & .833 & 16.661 & 80.285 & & & \\
3 & .614 & 12.271 & 92.556 & & & \\
4 & .249 & 4.982 & 97.538 & & & \\
5 & .123 & 2.462 & 100.000 & & & \\
\hline
\end{tabular}

According to table 3, 1 factor has emerged from the analysis with the eigenvalue more than 1 with $63 \%$ variance explained. This factor is named Social Support at work, which measures the social support received by the IT Executives at work.

\subsection{Job Control (Empowerment)}

Table 4: Total Variance Explained \& Eigenvalue of Empowerment

\begin{tabular}{|c|c|c|c|c|c|c|}
\hline \multicolumn{7}{|c|}{ Variance Explained } \\
\hline \multirow{2}{*}{ Component } & \multicolumn{5}{|c|}{ Exial Eigenvalues } & \multicolumn{3}{|c|}{ Extraction Sums of Squared Loadings } \\
\cline { 2 - 7 } & Total & \% of Variance & Cumulative \% & Total & $\%$ of Variance & Cumulative \% \\
\hline 1 & 2.748 & 68.695 & 68.695 & 2.748 & 68.695 & 68.695 \\
2 & .721 & 18.024 & 86.719 & & & \\
3 & .361 & 9.030 & 95.749 & & & \\
4 & .170 & 4.251 & 100.000 & & & \\
\hline
\end{tabular}

Listed in table 4 are the results of factor analysis done on the items representing the Job Control (empowerment) of the IT Executives jobs. One factor emerges with eigenvalue more than 1 and named Job Control.

\subsection{Job Control (Skills Discretion)}

Table 5: Total Variance Explained \& Eigenvalue of Skills Discretion

\begin{tabular}{|c|c|c|c|c|c|c|}
\hline \multicolumn{7}{|c|}{ Variance Explained } \\
\hline \multirow{2}{*}{ Component } & \multicolumn{5}{|c|}{ Initial Eigenvalues } & \multicolumn{3}{|c|}{ Extraction Sums of Squared Loadings } \\
\cline { 2 - 7 } & Total & \% of Variance & Cumulative \% & Total & $\%$ of Variance & Cumulative \% \\
\hline 1 & 2.641 & 66.029 & 66.029 & 2.641 & 66.029 & 66.029 \\
2 & .739 & 18.487 & 84.517 & & & \\
3 & .365 & 9.131 & 93.647 & & & \\
4 & .254 & 6.353 & 100.000 & & & \\
\hline
\end{tabular}

According to table 5, the analysis resulted in one factor with the eigenvalue more than 1 with $66 \%$ total variance explained. This factor is named Job Control (Skills Discretions) and measures the IT executives skills discretions at work. 


\section{Turnover Intention}

Table 6: Total Variance Explained \& Eigenvalue of Turnover Intention

Total Variance Explained

\begin{tabular}{|c|c|c|c|c|c|c|}
\hline \multirow{2}{*}{ Component } & \multicolumn{3}{|c|}{ Initial Eigenvalues } & \multicolumn{3}{c|}{ Extraction Sums of Squared Loadings } \\
\cline { 2 - 7 } & Total & \% of Variance & Cumulative \% & Total & \% of Variance & Cumulative \% \\
\hline 1 & 1.548 & 51.589 & 51.589 & 1.548 & 51.589 & 51.589 \\
2 & 1.050 & 34.995 & 86.585 & 1.050 & 34.995 & 86.585 \\
3 & .402 & 13.415 & 100.000 & & & \\
\hline
\end{tabular}

Table 6 depicts the results of factor analysis done on the independent variable which is turnover intention. Two factors emerged with eigenvalues more than 1. The two factors emerged as a result of low factor loading for the second item used this variable. Table 7 showed the factor loadings of the items. Since the item loading is low, the study will omit this item and table 8 showed the improved variance explained after the item has been deleted.

Table 7: Factor loadings of Turnover Intention

\begin{tabular}{|l|c|}
\hline & Component \\
\cline { 2 - 2 } & 1 \\
\hline I will likely actively look for new job in the next year. & .856 \\
I often think about quitting. & .147 \\
I probably look for a new job in the next year. & .891 \\
\hline
\end{tabular}

Extraction Method: Principal Component Analysis.

a. 1 components extracted.

Table 8: Eigenvalue and Total Variance Explained for Turnover Intention after the deletion of 1 item

Total Variance Explained

\begin{tabular}{|c|c|c|c|c|c|c|}
\hline \multirow{2}{*}{ Component } & \multicolumn{3}{|c|}{ Initial Eigenvalues } & \multicolumn{3}{c|}{ Extraction Sums of Squared Loadings } \\
\cline { 2 - 7 } & Total & \% of Variance & Cumulative \% & Total & \% of Variance & Cumulative \% \\
\hline 1 & 1.540 & 77.018 & 77.018 & 1.540 & 77.018 & 77.018 \\
2 & .460 & 22.982 & 100.000 & & & \\
\hline
\end{tabular}

Extraction Method: Principal Component Analysis.

\subsection{Summary of Factor Analysis}

All but one of the variables (Turnover Intention) used in this study had produced results as expected whereby all items used for the different variables had recorded high factor loadings and recorded acceptable variances and eigenvalues of more than 1. For the variable named turnover intention, this study has deleted one of the original items and as expected the variance explained increased and thus only one factor emerged with eigenvalue more than 1 (refer to table 8) with increased variance explained from $55 \%$ to $77 \%$.

\subsection{Reliability Analysis}

Table 9: Reliability Analysis of the Observed Variables

\begin{tabular}{|l|c|c|}
\hline Observed Variables & No of Items & Cronbach's Alpha \\
\hline Physical Demand & 4 & 0.832 \\
\hline Mental Demand & 4 & 0.804 \\
\hline Social Support & 5 & 0.856 \\
\hline Empowerment & 4 & 0.848 \\
\hline Skills Discretion & 4 & 0.827 \\
\hline Turnover Intention & 2 & 0.701 \\
\hline
\end{tabular}


Table 9 depicts the results of the reliability analysis.

The results of the reliability test conducted on the items showed that all of the items used in the constructs measurements for all the variables are reliable. The Cronbach's alpha values ranges from 0.701-0.856 whereby the lowest value is recorded by the turnover intention items and the highest being the items representing social support at work.

\section{Findings: Descriptive Statistics}

This part will describe the types of respondents that participated in this study according to various characteristics. Most of the IT executives were almost equally represented with Malays executives represents $34.5 \%$, Chinese with a $32.17 \%$ and Indian with $31.7 \%$ representation. Genders were also almost equally represented with female having slightly more representation (51\%) than their male counterparts which was represented at $49 \%$. Many respondents are those between the age of 31-39 years old with a representation of 32\%; followed by executives aged between 40 and 45 years old. Majority of respondents hold a bachelor degree (55\%) and the respondents were also distributed almost evenly with regards to the positions they hold in their companies (Executives: 26\%; Senior Executives: 30\% and managers: 29\%). Interesting enough, $48 \%$ of the respondents had spent less than 5 years at their individual companies whereby another $52 \%$ had been employed in the present companies for more than 5 years. As far as salary is concern, most of the respondents received salaries ranging from RM 4,000 to RM 6,000 (47\%) whereby only $22 \%$ of the respondents received more than RM 6,000 per month.

The descriptive statistics discussed previously stated that for many of the description criteria, most of the respondents were almost equally represented and this could suggest that the results of the later analysis will not be bias towards only one quarter of executives with certain distinct character; but can be taken as a single group, which IT executive is.

\section{Hypotheses Testing}

This part will discuss the results of statistical analysis done in order to confirm or reject the hypotheses presented earlier. The first hypothesis was: Intentions to quit among IT Executives are high. In order to test this, these scales of mean are derived and categorized as follow:

High: Mean Value of more than 4.3

Medium: Mean Value of between; 2.7 and 4.2

Low: Mean Value of between 0 and 2.6

A mean value statistics was performed on the data collected that represents the IT Executives turnover intention and the results are as follow:

\begin{tabular}{|c|c|c|c|c|c|}
\hline & $\mathrm{N}$ & Minimum & Maximum & Mean & Std. Deviation \\
\hline Turnover Intention & 258 & 1.00 & 5.00 & 3.4477 & 1.11419 \\
\hline
\end{tabular}

According to the table above it is apparent that the IT Executives are experiencing medium levels of Intention to quit. The mean value captured is within the range allocated for medium experiences.

To test the second, third and fourth hypotheses, Pearson Correlation analysis were conducted with the data available and the results are shown in the tables below:

Table 10: Relationship between Job Demand and Turnover Intention

\begin{tabular}{|ll|c|c|}
\hline \multicolumn{2}{c|}{ Correlations } \\
\hline \multirow{3}{*}{ Turnover Intention } & Turnover Intention & Demand@Work \\
& Pearson Correlation & 1 & $.158^{*}$ \\
& Sig. (2-tailed) & & .016 \\
& $\mathrm{~N}$ & 231 & 231 \\
& Pearson Correlation & $.158^{*}$ & 1 \\
Demand@Work & Sig. (2-tailed) & .016 & \\
& $\mathrm{~N}$ & 231 & 231 \\
\hline
\end{tabular}

*. Correlation is significant at the 0.05 level (2-tailed). 
Table 11: Relationship between Social Support@Work and Turnover Intention

\section{Correlations}

\begin{tabular}{|ll|c|c|}
\hline & & Turnover Intention & Social Support@Work \\
\hline \multirow{4}{*}{ Turnover Intention } & Pearson Correlation & 1 & .094 \\
& Sig. (2-tailed) & & .153 \\
& $\mathrm{~N}$ & 231 & 231 \\
& Pearson Correlation & .094 & 1 \\
Social Support@Work & Sig. (2-tailed) & .153 & \\
& $\mathrm{~N}$ & 231 & 231 \\
\hline
\end{tabular}

*. Correlation is significant at the 0.05 level (2-tailed).

Table 12: Relationship between Control@Work and Turnover Intention

\begin{tabular}{|ll|c|c|}
\hline \multicolumn{2}{c}{ Correlations } \\
\hline \multirow{4}{*}{ Turnover Intention } & Turnover Intention & Control@Work \\
& Pearson Correlation & 1 & $.139^{*}$ \\
& Sig. (2-tailed) & & .035 \\
& $\mathrm{~N}$ & 231 & 231 \\
& Pearson Correlation & $.139^{*}$ & 1 \\
Control@Work & Sig. (2-tailed) & .035 & \\
& $\mathrm{~N}$ & 231 & 231 \\
\hline
\end{tabular}

*. Correlation is significant at the 0.05 level (2-tailed).

Table 10 showed that the relationship between demand at work \& intention to quit is a significant one. However so, the degree of associations between the two variables are very poor $(p=0.16 ; r=0.158)$. Therefore this hypothesis is accepted solely on the significant level of 0.16 . Meanwhile table 11 depicts the relationship between support at work and intention to quit. The results showed that there is no significant relationship between the two variables whereby the $p$-value obtained is more than than $0.05(p=0.153 ; r=0.09)$. Therefore this hypothesis is rejected. Table 12 depicts the relationship between control at work and intention to quit. The results depicted that there is a significant relationship between these two variables ( $p=0.035 ; r=0.135)$. Although the hypothesis is accepted, the degree of associations between the variables is very low.

As far as the fifth hypothesis is concern, a regression analysis was conducted on the data available and the results are as follows:

\begin{tabular}{|c|c|c|c|c|}
\hline Model & $R$ & R Square & Adjusted R Square & Std. Error of the Estimate \\
\hline 1 & $.131^{\mathrm{a}}$ & .017 & .005 & 1.11113 \\
\hline
\end{tabular}

a. Predictors: (Constant), Demand@Work, Support@Work, Control@Work

\begin{tabular}{|c|c|c|c|c|c|c|}
\hline & Model & Sum of Squares & df & Mean Square & $\mathrm{F}$ & Sig. \\
\hline & Regression & 5.451 & 3 & 1.817 & 1.472 & $.223^{b}$ \\
\hline & Residual & 313.593 & 254 & 1.235 & & \\
\hline & Total & 319.044 & 257 & & & \\
\hline
\end{tabular}

a. Dependent Variable: Intention to quit

b. Predictors: (Constant), Demand@Work, Support@Work, Control@Work

\begin{tabular}{|c|c|c|c|c|c|c|}
\hline \multicolumn{7}{|c|}{ Coefficients $^{a}$} \\
\hline & \multirow{2}{*}{ Model } & \multicolumn{2}{|c|}{ Unstandardized Coefficients } & \multirow{2}{*}{\begin{tabular}{|c} 
Standardized Coefficients \\
Beta
\end{tabular}} & \multirow{2}{*}{$\mathrm{t}$} & \multirow{2}{*}{ Sig. } \\
\hline & & B & Std. Error & & & \\
\hline \multirow{4}{*}{1} & (Constant) & 2.576 & .537 & & 4.798 & .000 \\
\hline & Demand@Work & .217 & .118 & .127 & 1.847 & .066 \\
\hline & Support@Work & -.059 & .130 & -.034 & -.457 & 648 \\
\hline & Control@Work & .076 & .120 & .045 & .629 & .530 \\
\hline
\end{tabular}

a. Dependent Variable: Intention to quit 
According to the tables above, the demand control variables are not significant in explaining the deviations in intention to quit. The ' $r$ ' value captured was too low that it had to be ignored seemingly suggesting that there is no predictability capability of the demand-control variables in explaining the turnover intentions of the IT Executives. F Statistics as well as T statistics were insignificant as well, and this further proved that the demand-control variables are unable to affect variations in the dependent variable.

Conclusively the hypotheses can be summarized as follows:

\begin{tabular}{|l|l|l|}
\hline$N_{0}$ & Hypotheses & Status \\
\hline $\mathrm{H}_{1}$ & The levels of Intention to quit among IT Executives are high & Rejected \\
\hline $\mathrm{H}_{2}$ & The is a relationship between Demand@Work and Turnover Intention & Accepted \\
\hline $\mathrm{H}_{3}$ & There is a relationship between Social Support@Work and Turnover Intention & Rejected \\
\hline $\mathrm{H}_{4}$ & There is a relationship between Control@Work and Turnover Intention & Accepted \\
\hline $\mathrm{H}_{5}$ & Demand Control variables significantly affect Turnover Intention & Rejected \\
\hline
\end{tabular}

\section{Conclusion}

The results of the analysis showed that the turnover intentions among the IT Executives were captured as medium (Mean: 3.45). The IT executives seemed not to have high levels of turnover intent. Also, this paper was set up and set out to access the ability of the famous demand-control model Karasek et. al, 1997) to predict the turnover intention of IT Executives working in MSC status companies in Malaysia. While the demand control model is able to predict many organizational behaviors (De Jonge et al, 2000; Elangovan et al, 2001; Karasek, 1990;1997), that same ability was tested and results showed that the demand control variables were unable to significantly explain turnover intentions among the subjects that were studied. In addition to that, only two of the variables suggested in the model have got associations with turnover intentions namely demand at work $(r=0.158)$ and control at work $(r=0.139)$. The $r$ values obtained were significantly low with the interpretation of both having low but significant relationships/ associations. Perhaps even; these low associations were also the contributors to the failure of the demand-control model to explain turnover intentions among the IT Executives who work for Multimedia Super corridor status companies in Malaysia.

\section{Discussions}

Demand control model that was suggested by Karasek $(1990 ; 1997)$ was an established model that have been used throughout research particularly those of concern with; job strain, occupational stress, burnout etc. The model's ability in explaining those phenomenon are without doubt encouraging and it can be safely hypothesized that the demand control model is significant in explaining stress related behaviors. This paper however is trying to link the ability of this same model in explaining intention to quit. As what the results suggested, mix results were obtained. Out of the three variables that were tested against turnover intention, two proved to be significant; which are job demand and control at work. Although the statistics suggested that there are associations; the low $r$ value obtained may suggest that the associations are quite low and therefore could be partially ignored. Another plausible explanation is that there are probably other factors that could better explain the variations in the dependent variable. According to previous research, factors such as retirement benefits, job security and financial crises (Khan S.A., 2014); distributive justice, workload, resource inadequacy, supervisory support, kinship support, and job satisfaction (Chen, X., Xu, H., Yuan, P., Fang, F., Huss, M., Vega, V. B. \& Ng, H. H, 2008) and many others; are more associated with turnover intention. The demand control model and was not able to explain turnover intention and with this outcome; the study is suggesting that this predictor ability doesn't exist. It is therefore safe to say that even though the demand control model was very useful in predicting job strain, it's not too useful in explaining turnover. Future research might want to look into any other variables that could be associated with the demand control model such as job satisfaction, job security and others.

\section{References}

Aizzat, M. N., Ramayah T., Mohamad, A. H., \& Seow, L. V. (2003). Job satisfaction and turnover intentions: A study among academicians. The Proceedings of the 5th Asian Academy of Management Conference, "Challenges of Globalized Business: The Asian Perspective", 10th - 13th September, 2003, Hyatt Hotel, Kuantan, Pahang, Malaysia

Ajzen, I. \& Fishbein, M. (1980). Understanding attitudes and predicting social. Behavior. Englewood Cliffs, NJ: Prentice Hall

Alexander, J. A., Richard L., Hyun J. O., \& Esther U. (1998). A Causal Model of Voluntary Turnover among Nursing Personnel in LongTerm Psychiatric Settings. Research in Nursing and Health, 21, 415-27 
Allen, T. (2001). Family-supportive work environments: The role of organizational perceptions. Journal of Vocational Behavior, 58, 414 435

Auerbach, S. M, Clore, J. N., Kiesler, D. J., Orr, T., Pegg, P. O., Quick, B. G., \& Wagner, C. (2002). Relation of diabetic patients' healthrelated control appraisals and physician-patient interpersonal impact to patients' metabolic control and satisfaction with treatment. Journal of Behavioral Medicine, 25, 17-35

Batra, G., \& Tan, H. (2003). SME technical efficiency and its correlates: Cross-national evidence and policy implications. World Bank, Washington, $D C$

Borda, R. G., \& Norman, I. J. (1997). Factors influencing turnover and absence of nurses: a research review. International Journal of Nursing Studies, 34 (6), 385-394

Bosma, H., Peter, R., Siegrist, J., \& Marmot, M. (1998). Two alternative job stress models and the risk of coronary heart disease. American Journal of Public Health, 88 (1), 68-74

Bureau of Labor Statistics, United States. (1966)

Chen, G., Ployhart, R. E., Thomas, H. C., Anderson, N., \& Bliese, P. D. (2011). The power of momentum: A new model of dynamic relationships between job satisfaction change and turnover intentions. Academy of Management Journal, 54 (1), 159-181

Chen, X., Xu, H., Yuan, P., Fang, F., Huss, M., Vega, V. B. \& Ng, H. H. (2008). Integration of external signaling pathways with the core transcriptional network in embryonic stem cells. Cell, 133 (6), 1106-1117

De Jonge, J., Dollard, M. F., Dormann, C., Le Blanc, P. M., \& Houtman, I. L. (2000). The demand-control model: Specific demands, specific control, and well-defined groups. International Journal of Stress Management, 7 (4), $269-287$

Demerouti, E., Bakker, A. B., Nachreiner, F., \& Schaufeli, W. B. (2001). The job demands-resources model of burnout. Journal of Applied psychology, 86 (3), 499

Department of Statistics, Malaysia. (2005). Retrieved on April 10, 2014 from www.statistics.gov.my

Department of Statistics, Malaysia. (2011). Retrieved on April 10, 2014 from www.statistics.gov.my

Department of Statistics, Malaysia. (2012). Retrieved on April 10, 2014 from www.statistics.gov.my

Elangovan, A. R. (2001). Causal ordering of stress, satisfaction and commitment, and intention to quit: a structural equations analysis. Leadership \& Organization Development Journal, 22(4), 159-165

Firth, L., Mellor, D. J., Moore, K. A., \& Loquet, C. (2003) How can managers reduce employee intention to quit? Journal of Managerial Psychology, 19 (2), 170-186

Gärtner, T. (2000). Kernel-based feature space transformation in inductive logic programming. Master's thesis, University of Bristol

Graham, K. S. (1999). Semantic dementia: A challenge to the multiple-race theory? Trends in Cognitive Sciences, 3, pp. 85-87

Hoel, H., Sparks, K., \& Cooper, C. L. (2000). The cost of violence/stress at work and the benefits of a violence/stress-free working environment. Geneva: International Labour Organization

Hom, P., \& Griffeth, R. (1995). Employee turnover. Cincinnati: South-Western

Houkes, I., Janssen, P. P., de Jonge, J., \& Nijhuis, F. J. (2001). Work and individual determinants of intrinsic work motivation, emotional exhaustion, and turnover intention: A multi-sample analysis. International Journal of Stress Management, 8 (4), 257-283

Igbaria, M., \& Greenhaus, J. H. (1992). Determinants of MIS employees' turnover intentions: a structural equation model. Communications of the ACM, 35 (2), 34-49

Jaros, S. J. (1997). An assessment of Meyer and Allen's (1991) three-component model of organizational commitment and turnover intentions. Journal of vocational behavior, 51 (3), 319-337

Jaros, S., Jermier, J., Koehler, J., \& Sincich, T. (1993). Effects of continuance, affective and moral commitment on the withdrawal process: An evaluation of eight structural equation models. Academy of Management Journal, 36, 951-995

Johnson, J. V. (1986). The impact of workplace social support and work control upon cardiovascular disease in Sweden. Stockholm: Division of Environmental and Organizational Psychology

Jones, E., Chonko, L., Rangarajan, D., \& Roberts, J. (2007). The role of overload on job attitudes, turnover intentions, and salesperson performance. Journal of Business Research, 60 (7), 663-671

Jonge, J. D., Janseen, P. P., \& Van Breukelen, G. J. (1996). Testing the demand-control-support model among health-care professionals: A structural equation model. Work \& Stress, 10 (3), 209-224

Karasek Jr, R. A. (1979). Job demands, job decision latitude, and mental strain: Implications for job redesign. Administrative science quarterly, 285-308

Karasek, R. A. (1990). Lower health risk with increased job control among white collar workers. Journal of Organizational Behavior, 11 (3), $171-185$

Karasek, R. A. (1997). Demand/control model: A social, emotional, and physiological approach to stress risk and active behavior development. In ILO Encyclopedia of Occupational Health and Safety. Geneva: ILO

Karasek, R. A., \& Theorell, T. (1990). Healthy work: Stress, productivity, and the reconstruction of working life. New York: Basic Books

Kim, S. W., Price, J. L., Mueller, C. W., \& Watson, T. W. (1996). The Determinants of Career Intent Among Physicians at a U.S. Air Force Hospital. Human Relations, 49 (7), 947-976

Krausz, M., Koslowsky, M., \& Eiser, A. (1998). Distal and proximal influences on turnover intentions and satisfaction: Support for a withdrawal progression theory. Journal of Vocational Behavior, 52: 59-71

Kraut, A. I. (1975). Predicting turnover of employees from measured job attitudes. Organizational Behavior and Hitman Performance, 13, 233-243

Krejcie, R. V., \& Morgan, D. W. (1970). Determining sample size for research activities. Educational and psychological measurement 
Kristensen, T. S. (1995). The demand-control-support model: Methodological challenges for future research. Stress Medicine, 11, 17-26

Kristensen, T. S. (1996). Job stress and cardiovascular disease: A theoretical critical review. Journal of Occupational Health Psychology, $1,246-260$

Malinauskiene, V., Theorell, T., Grazuleviciene, R., Malinauskas, R., \& Azaraviciene, A. (2004). Low job control and myocardial infarction risk in the occupational categories of Kaunas men, Lithuania. Journal of Epidemiology and Community Health, 58 (2), 131-135

Michael Page International. (2012)

Mobley, W. C., Server, A. C., Ishii, D. N., Riopelle, R. J., \& Shooter, E. M. (1977). Nerve growth factor (three part article). New England Journal of Medicine, 297: 1096-1104; 1149-1158; 1211-1218

Mobley, W. H. (1977). Intermediate linkages in the relationship between job satisfaction and employee turnover. Journal of Applied Psychology, 62, 237-240

Nasurdin, A. M., Jantan, M., \& Ahmed, F. N. F. (2004). Country of origin effect on organizational innovation in Malaysia: The mediating role of structure. Asian Academy of Management Journal, 9 (2), 63-85

Nasurdin, A. M., Ramayah, T., \& Kumaresan, S. (2005). Organizational stressors and job stress among managers: The moderating role of neuroticism. Singapore Management Review, 27 (2), 63-79

Pattie, M., Benson, G. S., \& Baruch, Y. (2006). Tuition reimbursement, perceived organizational support, and turnover intention among graduate business school students. Human Resource Development Quarterly, 17 (4), 423-442

Price, J. L. (1997). Handbook or organizational measurement MCB. University Press, Bradford, UK

Price, J. L. (2000). Introduction to the special issue on employee turnover. Human Resource Management Review, 9 (4), 387-395

Price, J. L., \& Mueller, C.W. (1986). Absenteeism and Turnover among Hospital Employees. Journal of Artificial Intelligence. Press, Greenwich, CN

Rahim, M. A. (1997). Relationships of stress, locus of control, and social support to psychiatric symptoms and propensity to leave a job: A field study with managers. Journal of Business and Psychology, 12 (2), 159-174

Ross, T. (1996). Indices for performance evaluation of predictive references models in food microbiology. Journal of Applied Bacteriology, 81, 501-508

Sager, J. K., Griffeth, R. W., \& Hom, P. W. (1998). A comparison of structural models representing turnover cognitions. Journal of Vocational Behavior, 53 (2), 254-273

Sager, J. K., Yi, J., \& Futrell, C. M. (1998). A model depicting salespeople's perceptions. Journal of Personal Selling \& Sales Management, 18 (3), 1-22

Schnall, P. L., \& Landsbergis, P. A. (1994). Job strain and cardiovascular disease. Annual Review of Public Health, 15, $381-411$

Shain, Y. (1999). Marketing the American creed abroad: Diasporas in the US and their homelands. Cambridge University Press

Siong, Z. M. B., Mellor, D., Moore, K. A., \& Firth, L. (2006). Predicting intention to quit in the call centre industry: Does the retail model fit? Journal of Managerial Psychology, 21 (3), 231-243

Steel, R. P., \& Ovalie, N. K. (1984). A review and meta-analysis on the relationship between behavioural intentions and employee turnover. Journal Applied Psychology, 69, pp. 673-686

Tsutsumi, A., Nagami, M., Morimoto, K., \& Matoba, T. (2002). Responsiveness of measures in the effort-reward imbalance questionnaire to organizational changes: A validation study. Journal of Psychosomatic Research, 52 (4), 249-256

Udo, G. J., Guimãrães, T., \& Igbaria, M. (1997). An investigation of the antecedents of turnover intention for manufacturing plant managers. International Journal of Operations \& Production Management, 17 (9), 912-930

Van Dyne, L., \& Pierce, J. L. (2004). Psychological ownership and feelings of possession: three field studies predicting employee attitudes and organizational citizenship behavior. Journal of Organizational Behavior, 25 (4), $439-459$

Viator, R. E. (2001). The relevance of transformational leadership to nontraditional accounting services: Information systems assurance and business consulting. Journal of Information Systems, 15 (2), 99-125

Wallgren, L. G., \& Hanse, J. J. (2007). Job characteristics, motivators and stress among information technology consultants: A structural equation modeling approach. International journal of industrial ergonomics, 37 (1), 51-59

World Bank. (2003). Review of Small Business Activities, Washington, DC: World Bank Group 